\title{
Analisis Tingkat Kepuasan Masyarakat terhadap Dimensi Kualitas Pelayanan Tenaga Pelaksana Eliminasi Menggunakan Pemodelan Rasch
}

\author{
Dini Riyantini Sari, ${ }^{1}$ Nanan Sekarwana, ${ }^{2}$ Zahrotur Rusyda Hinduan, ${ }^{3}$ Bambang Sumintono ${ }^{4}$ \\ ${ }^{1}$ Dinas Kesehatan Provinsi Jambi \\ ${ }^{2}$ Departemen/ SMF Ilmu Kesehatan Anak Fakultas Kedokteran Universitas Padjadjaran/ \\ Rumah Sakit Umum Pendidikan Hasan Sadikin \\ ${ }^{3}$ Fakultas Psikologi Universitas Padjadjaran \\ ${ }^{4}$ Institute of Educational Leadership, Universiti Malaya
}

\begin{abstract}
Abstrak
Jenis penyakit filariasis limfatik telah lama menjadi masalah kesehatan khususnya daerah endemis filariasis di Indonesia. Tahun 2014 angka mikrofilaria rate (Mf rate) di Kelurahan Nibung Putih sebesar 2,08\%. Tingginya prevalensi penyakit filariasis limfatik berhubungan dengan kualitas pelayanan Tenaga Pelaksana Eliminasi (TPE). Penelitian ini bertujuan menganalisis tingkat kepuasan masyarakat terhadap dimensi kualitas pelayanan TPE di Kelurahan Nibung Putih Kabupaten Tanjung Jabung Timur Provinsi Jambi. Instrumen yang digunakan adalah kuesioner berupa formulir pengumpulan data hasil modifikasi dari penelitian yang dilakukan oleh Valarei dan Nasution D.C. Pemodelan Rasch digunakan untuk analisis data kuesioner, desain penelitian ini adalah observasional analitik kuantitatif dengan metode survei, pendekatan waktu cross sectional studies pada bulan April 2016 dengan subjek warga Kelurahan Nibung Putih yang berjumlah 103 orang. Item pada masing-masing konstruk didapati mempunyai daya diskriminasi yang beragam, yang menunjukkan instrumen mempunyai kemampuan mengukur. Hasil analisis keseluruhan responden bahwa sebanyak 103 berada di atas rata-rata logit item $(+0,00$ logit $)$ yang menunjukkan persetujuan responden pada kualitas pelayanan. Hasil analisis univariat berdasarkan karakteristik responden dapat disimpulkan bahwa umur masa remaja akhir (42,9\%), jenis kelamin laki-laki $(55,2 \%)$, pendidikan tidak tamat SD $(66,7 \%)$, pekerjaan buruh dan karyawan swasta $(100 \%)$, memberikan penilaian sangat puas terhadap dimensi kualitas pelayanan TPE di Kelurahan Nibung Putih.
\end{abstract}

Kata Kunci: Kualitas Pelayanan, Pemodelan Rasch, Tenaga Pelaksana Eliminasi

\section{Analysis of Public Satisfaction Level of Service Quality Dimensions of Elimination Personnel Using Rasch Model}

\begin{abstract}
Type of lymphatic filariasis disease has long been a health problem particular endemic filariasis in Indonesia. In 2014 the numbers of Microfilariae rate (Mf rate) in Nibung Putih Village by 2.08\%. The high prevalence of the disease lymphatic filariasis related with service quality Elimination Personnel (EP). This study aimed to analyze the level of people's satisfaction in service quality dimensions EP Nibung Putih Village, East Tanjung Jabung, Jambi Province. The instrument used was the questionnaire forms for collecting data modification results from research conducted by Valarei and Nasution D.C. Rasch modeling used for the analysis of questionnaire data, this study design was observational analytic quantitative survey methods, the time approaches cross sectional studies in April 2016, with the subject Nibung Putih Village residents numbering 103 people. The items on each construct was found to have the power of discrimination is diverse, which indicates the instrument has the ability to measure. The results of the overall analysis of 103 respondents that are above average logit item $(+0.00$ logit) indicating approval of the respondents on the quality of service. Results of univariate analysis based on the characteristics of the respondents can be concluded that the age of late adolescence (42.9\%), male gender $(55.2 \%)$, did not finish primary education (66.7\%), employment of workers and private employees $(100 \%)$, providing an assessment very satisfied with the service quality dimensions EP in Nibung Putih Village.
\end{abstract}

Keywords: Elimination Personnel, Quality Service, Rasch Model

Korespondensi:

Dini Riyantini Sari T.dr., MKM

Dinas Kesehatan Provinsi Jambi

Jl. R.M Nur Athmadibrata No.01 Kel. Pematang Sulur Kec. Telanaipura Kota Jambi

Mobile : 08117401300

Email :dini_jambi@yahoo.com 


\section{Pendahuluan}

Filariasis limfatik atau penyakit kaki gajah adalah penyakit menular menahun yang disebabkan oleh cacing filaria yang menyerang saluran dan kelenjar getah bening. Pada tahun 2004, filariasis limfatik telah menginfeksi 120 juta penduduk di 83 negara di seluruh dunia, terutama negaranegara di daerah tropis dan beberapa daerah subtropik. ${ }^{1}$ Berdasarkan survei yang dilaksanakan pada tahun 2000 hingga 2004, di Indonesia terdapat lebih dari 8.000 orang penderita klinis kronis filariasis limfatik (elephantiasis) yang tersebar di seluruh provinsi. Secara epidemiologi, data ini memberikan gambaran bahwa lebih dari 60 juta penduduk diantaranya telah terinfeksi. ${ }^{1}$ Pada tahun 2015, filariasis masih menjadi endemi di $241 \mathrm{kabupaten} /$ kota di Indonesia, 46 diantaranya telah melaksanakan Pemberian Obat Pencegahan Masal (POPM) filariasis selama 5 tahun. Sementara 195 kabupaten/kota akan melaksanakan POPM sampai dengan tahun 2020 dengan jumlah penduduk sebesar 105 juta jiwa yang merupakan sasaran dari kegiatan Bulan Eliminasi Kaki Gajah (BELKAGA). ${ }^{2}$

Penyakit filariasis limfatik dapat menyebabkan cacat seumur hidup serta stigma sosial bagi penderita serta keluarganya. Kecacatan yang dialami mengakibatkan penderita tidak dapat bekerja secara optimal dan hidupnya tergantung kepada orang lain sehingga menjadi beban keluarga, masyarakat dan negara. Hasil penelitian Departemen Kesehatan dan Fakultas Kesehatan Masyarakat Universitas Indonesia tahun 1998, menunjukan bahwa biaya perawatan yang diperlukan seorang penderita filariasis limfatik pertahun mencapai sebesar Rp. 735.380,- bila diperhitungkan inflasi sampai tahun 2016 ratarata sebesar $6 \%$ per tahun maka nilainya menjadi Rp. 1.529 .590 atau setara dengan $17,8 \%$ dari seluruh pendapatan keluarga atau 32,3\% dari biaya makan. ${ }^{3,4}$

Provinsi Jambi menempati peringkat ke-3 untuk regional Sumatera sebagai penyumbang penderita filariasis limfatik terbanyak dengan 341 penderita kasus kronis, setelah Provinsi Nanggroe Aceh Darussalam (NAD) dan Provinsi Riau. ${ }^{4}$ Provinsi Jambi memiliki 5 kabupaten yang endemis filariasis limfatik, yaitu Kabupaten Tanjung Jabung Barat, Kabupaten Muaro Jambi, Kabupaten Merangin, Kabupaten Batanghari, dan Kabupaten Tanjung Jabung Timur. ${ }^{4}$ Berdasarkan penelitian Lokalitbang Pengendalian Penyakit Bersumber Binatang (P2B2) tahun 2014, melalui survei darah jari di dapat angka mikrofilaria rate (Mf rate) tertinggi di Kelurahan Nibung Putih Kabupaten Tanjung Jabung Timur sebesar 2,08\%. ${ }^{5}$ Berdasarkan ketentuan Kementerian Kesehatan
Republik Indonesia, jika Mf rate $>1 \%$ di salah satu atau lebih lokasi survei maka kabupaten/ kota tersebut ditetapkan sebagai daerah endemis filariasis limfatik dan harus melaksanakan pengobatan massal.

Menurut Sugiyanto (2012) prevalensi penyakit filariasis limfatik berhubungan dengan kualitas pelayanan yang diberikan oleh Tenaga Pelaksana Eliminasi. ${ }^{6}$ Selain itu faktor karakteristik penduduk berhubungan dengan kepuasan terhadap kualitas pelayanan (Anjaryani, 2009). ${ }^{7}$ Penelitian lain yang dilakukan Martina (2011) menyatakan bahwa kualitas pelayanan kesehatan (tangible, reliability, responsiveness, assurance, dan empathy) berpengaruh secara signifikan terhadap kepuasan pasien. ${ }^{8}$ Penelitian ini berusaha menganalisis dimensi kualitas pelayanan TPE dalam program POPM filariasis limfatik berdasarkan persepsi dan karakteristik responden dengan menggunakan pendekatan pemodelan Rasch.

\section{Metode}

Penelitian dilaksanakan di Kelurahan Nibung Putih Kecamatan Muara Sabak Barat Kabupaten Tanjung Jabung Timur Provinsi Jambi mulai bulan April sampai Mei 2016. Pemodelan Rasch digunakan untuk analisis data kuesioner, desain penelitian ini adalah observasional analitik kuantitatif dengan metode survei. Pendekatan waktu cross sectional studies pada bulan April 2016 dengan subjek warga Kelurahan Nibung Putih yang berjumlah 103 orang. Penelitian ini telah mendapatkan persetujuan dari Komite Etik Penelitian Kesehatan Fakultas Kedokteran Universitas Padjadjaran dengan Ethical Approval Nomor.240/UN6.C1.3.2/KEPK/PN/2016. Kriteria inklusi dalam penelitian ini adalah warga yang berumur diatas 21 tahun, berdomisili di Kelurahan Nibung Putih lebih dari 4 tahun, dan bersedia menjadi responden. Kriteria eksklusi dalam penelitian ini adalah warga yang menderita gangguan jiwa, tidak dapat berkomunikasi

Penelitian ini mengukur satu variabel yaitu kualitas pelayanan. Aspek karakteristik responden yang dikumpulkan pada penelitian ini terdiri atas umur, jenis kelamin, pendidikan dan pekerjaan. Jenis skala yang digunakan untuk mengukur variabel dimensi kualitas pelayanan TPE filariasis limfatik adalah skala peringkat Likert dengan lima pilihan pernyataan. ${ }^{9}$ Definisi dan pengukuran dari variabel tersebut adalah sebagai berikut: kualitas pelayanan adalah perbedaan antara harapan customer atau keinginan customer dengan persepsi mereka terhadap pelayanan yang diterima. 
Penilaian kualitas pelayanan Tenaga Pelaksana Eliminasi menggunakan pendekatan 5 dimensi dalam model SERVQUAL (Service Quality) yaitu Tangible (Bukti Langsung), Reliability (Kehandalan), Responsiveness (Daya Tanggap), Assurance (Jaminan), Empathy (Perhatian) yang dikembangkan oleh Parasuraman A, dkk (dalam Kotler \& Keller, 2012). ${ }^{10}$

Jenis analisis untuk menilai persepsi masyarakat terhadap dimensi kualitas pelayanan TPE filariasis limfatik menggunakan pemodelan Rasch. Pemodelan Rasch merupakan alat analisis yang dapat menguji validitas (kesahan) dan reliabilitas instrumen riset, bahkan dapat menguji kesesuaian person dan item secara simultan. Analisis pengujian validitas instrumen pada penelitian ini menggunakan pemodelan Rasch, hal yang dilihat adalah tingkat validitas respon pada item berdasarkan nilai Outfit Mean Square (MNSQ) yang diterima $0,5<$ MNSQ $<1,5$, Outfit $Z$-Standard (ZSTD) kesesuaian nilai uji $\mathrm{z}$ yang diterima $-2,0<$ ZSTD $<+2,0$, dan Point Measure Correlation (Pt Mean Corr) $0,4<$ Pt Mean Corr $<0,85{ }^{11}$ Apabila butir-butir item instrumen kualitas pelayanan memenuhi setidaknya satu kriteria di atas maka item instrumen layak digunakan. Kesimpulan dari uji validitas adalah semua item dimensi kualitas pelayanan memenuhi kriteria fit statistik, sehingga instrumen dapat digunakan untuk penelitian.

Data mentah hasil pengukuran dari formulir pengumpulan data yang berbentuk skala ordinal kemudian ditransformasi menjadi skala interval menggunakan pemodelan Rasch dengan perangkat lunak Winsteps versi 3.73. Pemodelan Rasch mengatasi masalah keintervalan data dengan cara mengakomodasi transformasi logit, dengan menerapkan logaritma pada odd ratio data mentah yang didapatkan dari responden. ${ }^{12,13}$ Analisis univariat pada penelitian ini menunjukkan tingkat kepuasan responden terhadap dimensi kualitas pelayanan TPE dilihat dari sebaran peta Wright item dan person (karakteristik) yang dihasilkan dari Pemodelan Rasch.

\section{Hasil}

Hasil uji reliabilitas item pada instrumen kualitas pelayanan adalah 0,88 dan reliabilitas person test yang diperoleh adalah 0,97 termasuk dalam kategori bagus, sedangkan nilai Alpha Cronbach (KR-20) yang mengukur interaksi antar person dan item menunjukkan nilai reliabilitas yaitu 0,96 . Hasil ini menunjukkan bahwa data aktual yang diperoleh dalam uji instrumen penelitian sesuai dengan baik pada persyaratan pemodelan Rasch, sehingga instrumen penelitian layak (reliabel) untuk digunakan. Nilai separasi item sebesar empat mengandung makna bahwa terdapat empat kelompok tingkat kesulitan item yang tergolong sangat susah, susah, sedang, mudah yang menunjukkan item baik karena bisa mendiskriminasi. Nilai separasi person delapan mengandung makna terdapat delapan kategori kelompok jawaban heterogen yang dapat memisahkan tingkat persetujuan responden. Hasil separasi ini menunjukkan item dan person memiliki tingkat reliabilitas yang bagus.

Responden pada penelitian ini berjumlah 103 orang, dengan karakteristik umur, jenis kelamin, pendidikan, pekerjaan, seperti terdapat pada tabel 1. Berdasarkan tabel 1 golongan umur responden terbanyak berada pada masa dewasa awal (26-35 tahun) yaitu berjumlah 39 orang $(37,9 \%)$, responden mayoritas berjenis kelamin perempuan sebanyak 73 orang $(70,9 \%)$, karakteristik pendidikan responden terbanyak berada pada tingkat SD berjumlah 32 orang $(31,1 \%)$, karakteristik pekerjaan responden terbanyak berada pada IRT sebanyak 48 orang $(46,6 \%)$.

Kualitas Pelayanan TPE; Berdasarkan hasil analisis sebaran peta Wright person map pada gambar 1 dapat disimpulkan bahwa seluruh responden berada di atas nilai rata-rata logit item $(+0,00$ logit) sebanyak 103 orang (100\%) responden, artinya responden menilai kualitas pelayanan yang diberikan TPE dalam pelaksanaan program POPM filariasis limfatik dalam kategori baik.

Berdasarkan peta Wright pada Gambar 1 menunjukkan kolom sebelah kiri adalah kolom person, dan kolom sebelah kanan adalah kolom item. Item yang berada di atas nilai rata-rata logit item $(+0,00$ logit) mengandung arti bahwa item tersebut relatif sulit disetujui oleh responden dan item yang berada di bawah nilai rata-rata logit item mengandung arti item tersebut mudah disetujui oleh responden.

Kolom Tangible; Pada kolom bukti langsung item tersebar dari yang mudah sekali sesuai sampai yang susah sesuai, item-item tersebut memiliki daya diskriminasi yang baik dibanding item yang berada pada dimensi lainnya. Terdapat satu item yang berada di atas nilai rata-rata logit item, nilai logit $(+1,77$ logit $)$ yaitu item kode T4 dengan isi item pernyataan "Petugas menggunakan kelengkapan seragam seperti papan nama", item tersebut memiliki tingkat persetujuan relatif susah disetujui dibanding item lainnya. Hal ini bermakna sebagian responden mendapati petugas yang datang, tidak dengan kelengkapan seragam berupa papan nama.

Kolom Reliability; Pada kolom kehandalan ini terdapat tiga item yang berada di atas nilai 
Tabel 1 Karakteristik Responden

\begin{tabular}{clc}
\hline No & \multicolumn{1}{c}{ Variabel } & Jumlah Responden (Persen) \\
\hline $\mathbf{1}$ & Umur & \\
& Masa remaja akhir (17-25 tahun) & $7(6,8 \%)$ \\
& Masa dewasa awal (26-35 tahun) & $39(37,9 \%)$ \\
& Masa dewasa akhir (36-45 tahun) & $33(32,0 \%)$ \\
& Masa lansia awal (46-55 tahun) & $15(14,6 \%)$ \\
& Masa lansiaakhir (56-60 tahun) & $9(8,7 \%)$ \\
$\mathbf{2}$ & Jenis Kelamin & $30(29,1 \%)$ \\
& Laki-laki & $73(70,9 \%)$ \\
\multirow{3}{*}{ Perempuan } & \\
& Pendidikan & $32(31,1 \%)$ \\
& Sekolah Dasar (SD) & $23(22,3 \%)$ \\
& Sekolah Menengah Pertama (SMP) & $31(30,1 \%)$ \\
& Sekolah Menengah Atas (SMA) & $11(10,7 \%)$ \\
& Strata Satu (S1) & $6(5,8 \%)$ \\
& Tidak tamat sekolahdasar & \\
Pekerjaan & $48(46,6 \%)$ \\
& Ibu Rumah Tangga (IRT) & $22(21,4 \%)$ \\
& Petani & $1(1,0 \%)$ \\
& Buruh & $9(8,7 \%)$ \\
& Pedagang & $3(2,9 \%)$ \\
& Karyawan swasta & $6(5,8 \%)$ \\
& Pegawai Negri Sipil (PNS) & $5(4,9 \%)$ \\
& Honorer & $9(8,7 \%)$ \\
\hline \multirow{2}{*}{ Wiraswasta } & $103(100 \%)$ \\
\hline & &
\end{tabular}

rata-rata logit item dengan kode $\mathrm{R} 1(+0,12$ logit $)$, R4 (+0,8 logit) dan R7( $+0,16$ logit $)$, item-item tersebut merupakan satu kelompok konstruk mengukur hal yang sama, mengandung arti bahwa item-item tersebut memiliki tingkat diskriminasi yang relatif sama, karena hasil pengukuran menunjukan nilai logit yang kurang lebih sama. Ketiga item berisi pernyataan yang berhubungan dengan prosedur kerja TPE, pengetahuan TPE dan keterampilan TPE.

Kolom Responsiveness; Pada kolom daya tanggap terdapat satu item di bawah nilai ratarata logit kode P1 $(-1,24$ logit) dengan isi item pernyataan "Petugas menanggapi bila ada pertanyaan", artinya item tersebut memiliki tingkat persetujuan relatif hampir sangat mudah disetujui dibanding item lainnya yang bermakna TPE responsif pada responden.

Kolom Assurance; Pada kolom jaminan terdapat tiga item berada di antara rata-rata nilai logit item kode A1 $(+0,19$ logit $)$, A2 $(+0,12$ logit), A3 (-0,31 logit), artinya item-item tersebut memiliki tingkat persetujuan relatif sulit disetujui oleh responden. Item-item tersebut berisi pernyataan yang berhubungan dengan kemampuan TPE meyakinkan masyarakat, mengandung makna konstruk jaminan memiliki kualitas pelayanan relatif lebih susah untuk diterima dibanding dengan item yang berada pada dimensi lainnya.

Kolom Emphaty; Pada kolom perhatian terdapat satu item yang berada di atas nilai rata-rata logit item $(+4,71$ logit) yaitu item kode E1 dengan isi item pernyataan "Petugas memberikan nomor telepon yang bisa dihubungi untuk berkonsultasi" item tersebut memiliki tingkat persetujuan relatif sangat susah disetujui dibanding item lainnya. Hal tersebut mengandung makna hanya sedikit 
responden yang mendapati TPE memberikan nomor telepon untuk berkonsultasi.

Kualitas Pelayanan TPE Berdasarkan Karakteristik Responden; Berdasarkan peta Wright tentang karakteristik responden menunjukkan kolom sebelah kiri adalah kolom item, dan kolom sebelah kanan adalah kolom respoden. Responden yang berada di atas nilai rata-rata logit person $(+2,51$ logit $)$ mengandung arti bahwa responden tersebut lebih puas dengan kualitas pelayanan yang diberikan TPE, dibandingkan dengan responden yang berada di bawah nilai rata-rata logit person.
Karateristik Berdasarkan Umur; Berdasarkan sebaran peta wright Gambar 2 menunjukkan bahwa persentase yang sangat puas dengan kualitas pelayanan berdasarkan kelompok umur secara berurutan adalah remaja akhir (42,9\%), dewasa awal (42,5\%), dewasa akhir (40,6\%), lansia awal dan akhir (33,3\%). Hasil statistik uji analisis varian (Anova) bahwa tingkat penilaian sangat puas dan puas terhadap kualitas pelayanan TPE berdasarkan karakteristik umur tidak terdapat perbedaan yang signifikan, dengan nilai $\mathrm{F}=0,450, \mathrm{p}=0,772(\mathrm{p}>0,05)$.

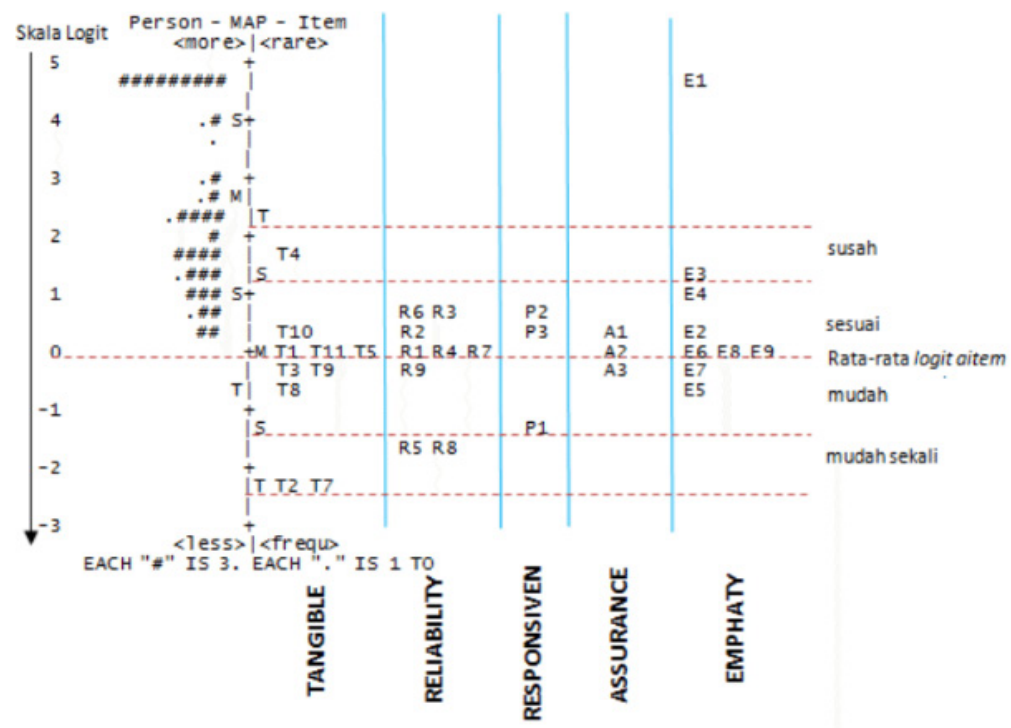

Gambar 1 Peta Wright Item Dimensi Kualitas Pelayanan TPE

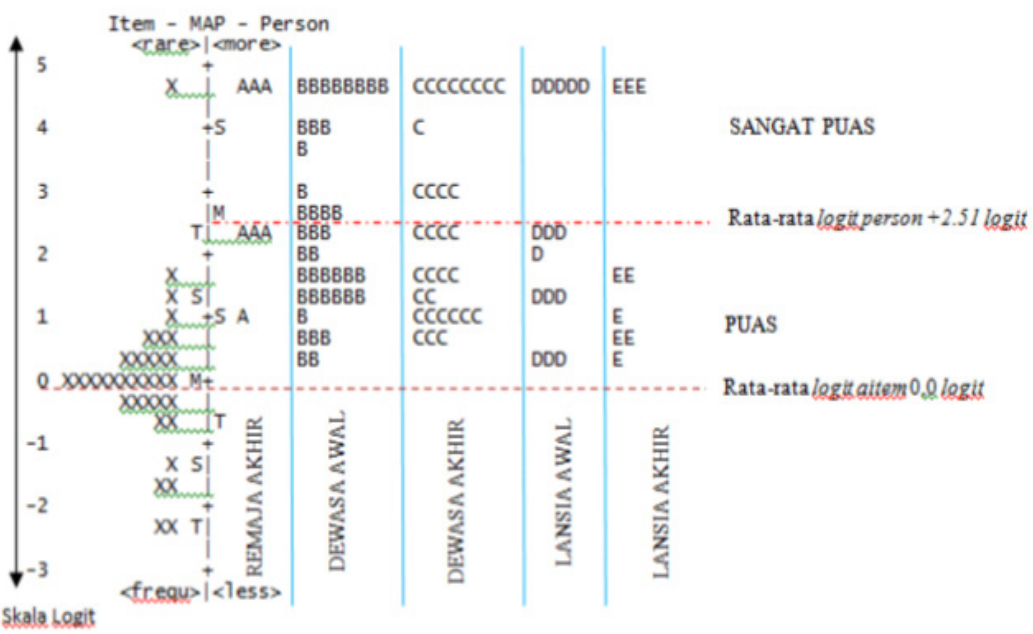

Gambar 2 Peta Wright Kualitas Pelayanan TPE 
Karakteristik Berdasarkan Jenis Kelamin; Berdasarkan sebaran peta Wright Gambar 3 menunjukkan bahwa persentase yang sangat puas dengan kualitas pelayanan berdasarkan kelompok jenis kelamin secara berurutan adalah jenis kelamin laki-laki sebesar 55,2\% sedangkan jenis kelamin perempuan adalah 33,8\%. Hasil uji analisis varian antara tingkat penilaian sangat puas dan puas terhadap kualitas pelayanan TPE berdasarkan karakteristik jenis kelamin tidak terdapat perbedaan yang signifikan, dengan nilai $\mathrm{F}=3,603, \mathrm{p}=0,061(\mathrm{p}>0,05)$.

Karakteristik Berdasarkan Pendidikan; Berdasarkan sebaran peta Wright Gambar 4 menunjukkan bahwa persentase yang sangat puas dengan kualitas pelayanan berdasarkan kelompok pendidikan secara berurutan adalah tidak tamat SD $(66,7 \%)$, pendidikan S1 $(45,4 \%)$, pendidikan SMA $(45,2 \%)$, pendidikan SD $(34,4 \%)$, pendidikan SMP $(30,4 \%)$. Hasil statistik uji beda berdasarkan karakteristik pendidikan bahwa tingkat penilaian sangat puas dan puas terhadap kualitas pelayanan TPE berdasarkan karakteristik pendidikan tidak terdapat perbedaan yang signifikan, dengan nilai $\mathrm{F}=1,520, \mathrm{p}=0,191(\mathrm{p}>0,005)$.

Karakteristik Berdasarkan Pekerjaan; Berdasarkan sebaran peta Wright Gambar 5 menunjukkan bahwa persentase yang sangat puas dengan kualitas pelayanan berdasarkan kelompok pekerjaan secara berurutan adalah pekerjaan buruh dan karyawan swasta $(100 \%)$, pekerjaan pedagang $(66,7 \%)$, pekerjaan honorer
$(60,0 \%)$, perkerjaan petani $(54,5 \%)$, pekerjaan PNS $(50,0 \%)$, pekerjaan wiraswasta $(33,3 \%)$, pekerjaan IRT $(20,8 \%)$. Hasil statistik uji beda bahwa tingkat penilaian sangat puas dan puas terhadap kualitas pelayanan TPE berdasarkan karakteristik pekerjaan terdapat perbedaan yang signifikan, dengan nilai $\mathrm{F}=3,942, \mathrm{p}=0,001$ $(\mathrm{p}<0,005)$.

Berdasarkan hasil pengukuran analisis karakteristik responden dapat disimpulkan bahwa responden rentang masa remaja akhir, jenis kelamin laki-laki, pendidikan tidak tamat $\mathrm{SD}$, pekerjaan buruh dan karyawan swasta, memberikan penilaian sangat puas terhadap kualitas pelayanan TPE di Kelurahan Nibung Putih. Hal ini berdasarkan jawaban dari responden pada formulir pengumpulan data dan secara keseluruhan responden tanpa melihat karakteristik demografi, responden yang puas dan sangat puas ternyata berbeda secara signifikan dengan nilai $F=377,672, p=<0,001(p<0,05)$.

\section{Pembahasan}

Kualitas pelayanan secara sederhana dapat diartikan seberapa baik tingkat layanan yang diberikan mampu memenuhi harapan dan kebutuhan masyarakat yang menjadi sasaran. Kualitas pelayanan TPE yang baik sangat memengaruhi kepatuhan masyarakat untuk mengikuti pengobatan filariasis limfatik sesuai

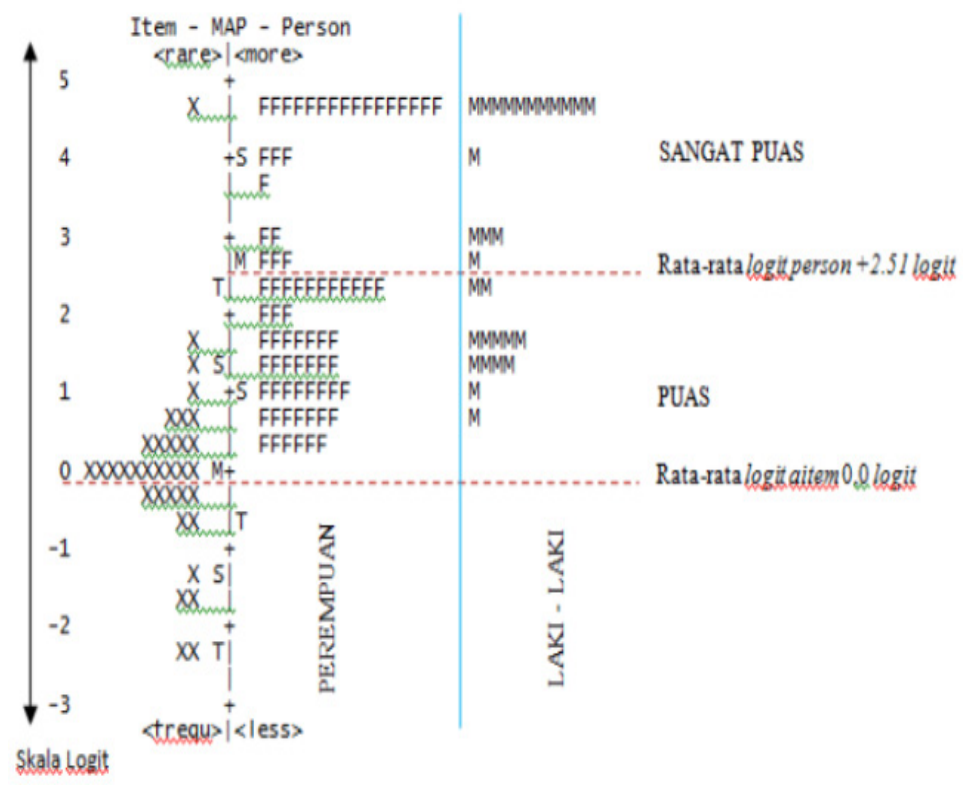

Gambar 3 Peta Wright Kualitas Pelayanan TPE 


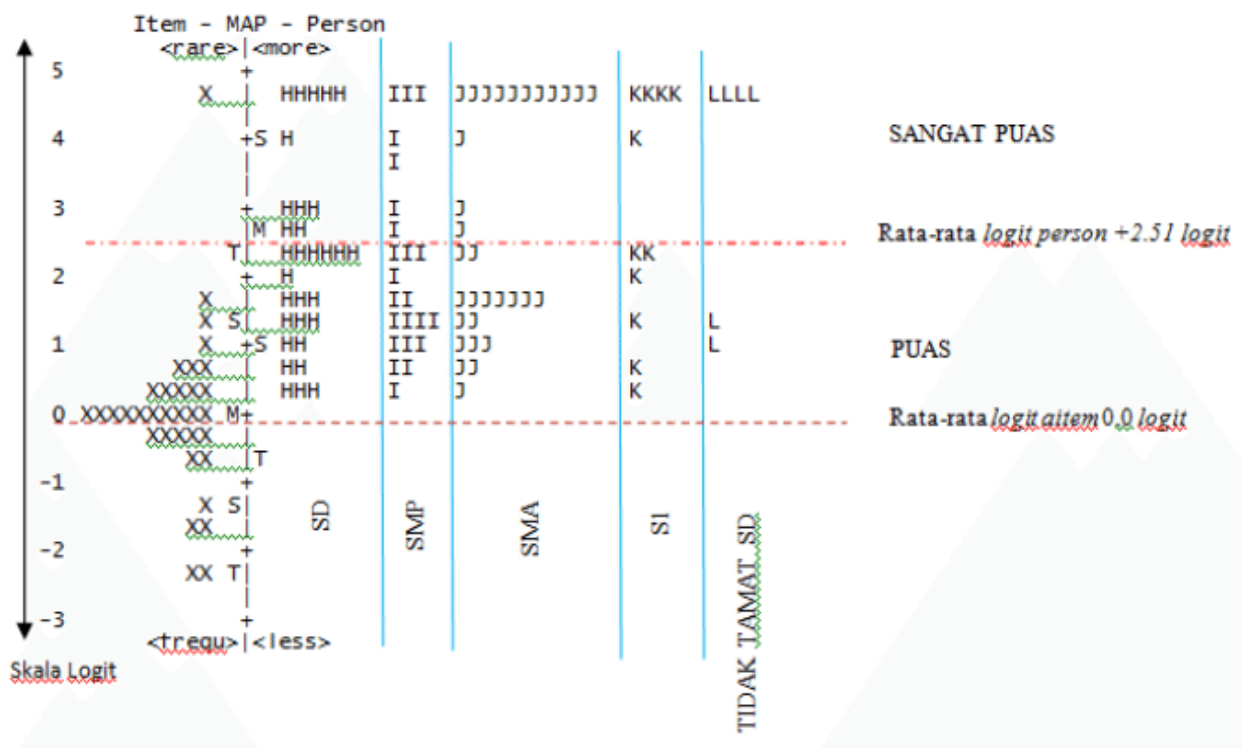

Gambar 4 Kualitas Pelayanan TPE

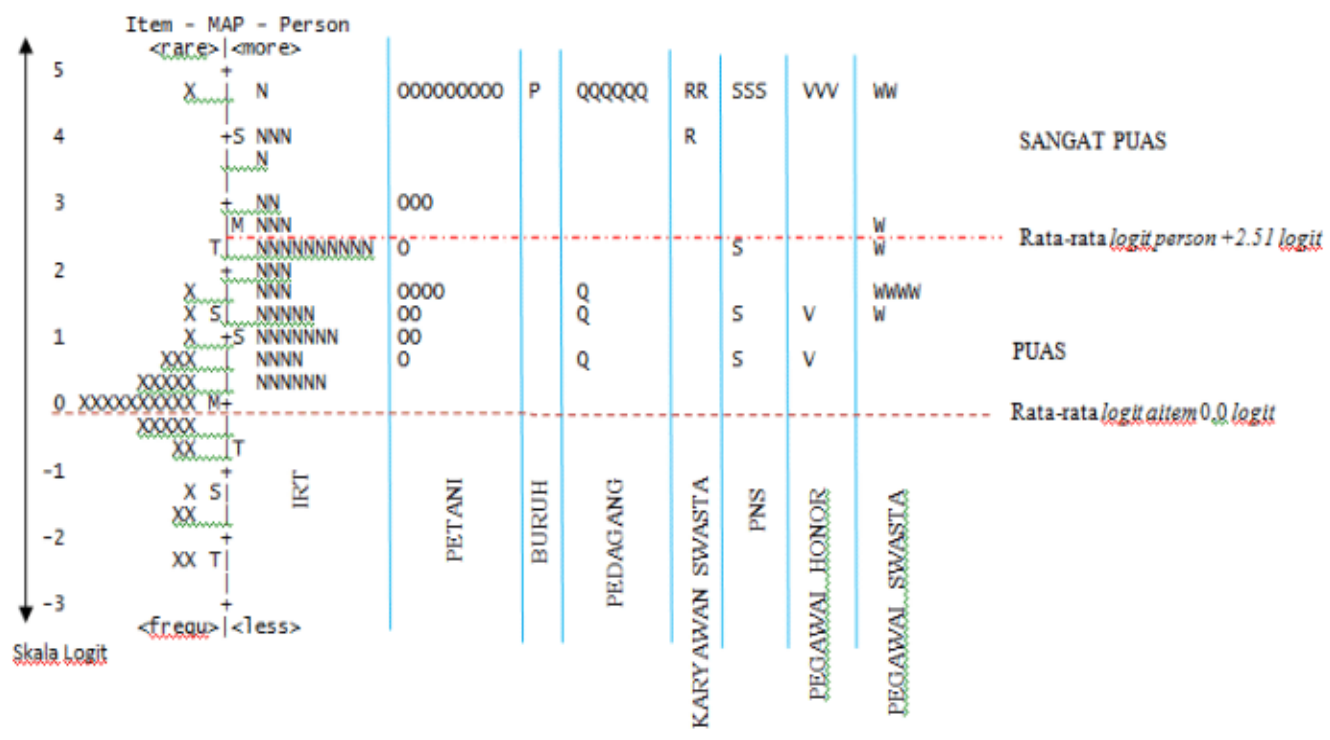

Gambar 5 Kualitas Pelayanan TPE

aturan yang telah ditetapkan. Kualitas pelayanan TPE sangat dipengaruhi oleh kemampuannya untuk memenuhi harapan masyarakat secara konsisten. ${ }^{14}$ Penelitian yang dilakukan oleh Khasanah I dan Pertiwi O.D (2010) menyatakan bahwa kualitas pelayanan berpengaruh secara signifikan terhadap kepuasan konsumen RS St. Elisabeth Semarang. ${ }^{15}$

Dimensi Tangible berkaitan dengan indikator yang memberikan gambaran fisik penyedia pelayanan seperti fasilitas fisik, perlengkapan, ruangan, dan penampilan karyawan. Hasil analisis pemodelan Rasch, kualitas pelayanan yang baik terdapat pada dimensi tangible (bukti langsung) dibandingkan dengan dimensi kualitas pelayanan lainnya, dimana seluruh responden menyetujui item-item pernyataan yang ada pada dimensi tangible. Berdasarkan hal tersebut dapat disimpulkan bahwa responden menilai fasilitas fisik, perlengkapan, ruangan, dan penampilan karyawan dalam pelaksanaan program POPM di Kelurahan Nibung Putih dalam kategori baik. 
Hasil penelitian yang dilakukan oleh Valentina (2012) menyebutkan bahwa faktor penentu kepuasan yang tertinggi secara berurutan adalah responsiveness, emphaty, assurance, reliability, dan tangible. ${ }^{16}$ Penelitian lain yang dilakukan oleh Herawati N. dan Qomariah H, menyebutkan bahwa variabel tangible, reliability, responsiveness, dan assurance berpengaruh positif terhadap kepuasan pasien puskesmas pengguna kartu PKMS. ${ }^{17}$ Menurut seorang ahli psikologi perkembangan, Santrock (1999), orang dewasa muda termasuk masa transisi, baik transisi secara fisik (physically trantition) transisi secara intelektual (cognitive trantition), serta transisi peran sosial (social role trantition). Sama halnya dengan penelitian ini responden dengan rentang umur masa remaja akhir sangat puas dengan kualitas pelayanan TPE. Hasil penelitian Venkatesh, dkk (2000) menyebutkan bahwa perilaku pria lebih besar didorong oleh sikap terhadap suatu layanan, sedangkan perilaku perempuan lebih besar didorong oleh norma subjektif sesuai yang dirasakan. ${ }^{18}$ Bila pelayanan yang diberikan baik, maka responden laki-laki akan cenderung sangat puas.

Terkait tingkat pendidikan, hasil penelitian menyebutkan responden dengan tingkat pendidikan tidak tamat SD lebih puas terhadap pelayanan TPE. Menurut Siagian (2012), semakin tinggi pendidikan seseorang menyebabkan tuntutan pelayanan yang berkualitas tinggi untuk mendapatkan kepuasan. ${ }^{19}$ Hal tersebut dapat diartikan bahwa seseorang yg berpendidikan rendah cenderung lebih mudah puas atas pelayanan yang diterima. Tingkat pendidikan tidak tamat SD termasuk kategori rendah sehingga termasuk kelompok yang lebih mudah puas. Berdasarkan penelitian yang dilakukan oleh Stefan, dkk (2013), menyatakan responden yang bekerja memiliki banyak tuntutan dan harapan akan pelayanan kesehatan yang dibutuhkan. Responden yang tidak bekerja pada

umumnya tidak memiliki tuntutan dan harapan yang tinggi terhadap pelayanan kesehatan..$^{20}$ Keterbatasan pada penelitian ini, penulis mengalami kesulitan dalam mengawasi petugas pada saat mengumpulkan data penelitian karena faktor geografis tempat penelitian.

Setelah instrumen melalui tahapan uji validitas maupun reliabilitas menggunakan pemodelan Rasch, diketahui instrumen penelitian baik dalam mengukur dimensi kualitas pelayanan TPE di Kelurahan Nibung Putih. Kualitas pelayanan tenaga pelaksana eliminasi dalam program POPM filariasis limfatik dalam kategori baik. Berdasarkan hasil pengukuran analisis karakteristik responden dapat disimpulkan bahwa responden rentang masa remaja akhir (17-25 tahun), jenis kelamin laki-laki, pendidikan tidak tamat SD, pekerjaan buruh dan karyawan swasta, memberikan penilaian sangat puas terhadap kualitas pelayanan TPE di Kelurahan Nibung Putih. Hal ini berdasarkan jawaban dari responden pada formulir pengumpulan data dan secara statistik perbedaan itu tidak signifikan. Berdasarkan keseluruhan responden responden yang puas dan sangat puas berbeda secara signifikan dengan nilai $F=377,672, p<0,001$ $(\mathrm{p}<0,05)$. Perlu adanya peningkatan kualitas pelayanan TPE, komitmen bersama TPE dalam pencapaian mutu kualitas pelayanan pada program POPM filariasis limfatik.

\section{Daftar Pustaka}

1. Kementerian Kesehatan RI. Buletin filariasis. Buletin Jendela. 2010;1:1-20.

2. Prevalansi penyakit kaki gajah (filariasis) berhasil diturunkan. [diunduh 1 Agustus 2016]. Tersedia dari: http://www.depkes. go.id/article/view/15073000001/prevalansipenyakit-kaki-gajah-filariasis-berhasilditurunkan.html\#sthash.jbkNCvce.dpuf

3. Menteri Kesehatan RI. Peraturan Menteri Kesehatan Republik Indonesia No.94 Tahun 2014 tentang penanggulangan filariasis. 2014 [diunduh 19 November 2015]. Tersedia dari: http://www.depkes.go.id/ resources/download/info-terkini/PMK\%20 No.\%2094\%20ttg\%20Penanggulangan $\% 20$ Filariasis.pdf

4. Kemenkes RI dan WHO. Pedoman bulan eliminasi kaki gajah. Jakarta: Kemenkes RI; 2014:1-4.

5. Dirjen PP \& PL Kemneks RI. Laporan tahunan pelaksanaan program eliminasi filariasis tahun 2014. Jakarta: Kemneks RI; 2015.

6. Sugiyanto. Analisis faktor-faktor yang berhubungan dengan ketidakpatuhan minum obat filariasis pada kegiatan pengobatan massal tahun 2010 di wilayah Puskesmas Soreang Kabupaten Bandung. ISJD. 2012;2(1):1-64.

7. Anjaryani WD. Kepuasan pasien rawat inap terhadap pelayanan perawat di RSUD Tugurejo Semarang. 2009 [diunduh 14 Agustus 2016]. Tersedia dari: https://core. ac.uk/download/files/379/11722783.pdf.

8. Martina. Pengaruh kualitas pelayanan kesehatan terhadap kepuasan pasien rawat inap RSUD Cut Meutia Kabupaten Aceh Utara. Universitas Sumatra Utara Medan. 2011 [diunduh 24 Agustus 2016]. Tersedia dari: www.repository.usu.ac.id/ 
bitstream/123456789/23325/7/Cover.pdf

9. Jamieson S., Likert Scales "How To Abuse Them "Blackwell Publishing Ltd Medical Education 2004 38: 1212-1218

10. Kotler P, Keller KL. Marketing management. Edisi ke-14. New Jersey: Pearson Education Inc; 2012.

11. Sumintono B, Widhiarso W. Aplikasi model rasch untuk penelitian ilmu-ilmu sosial. Edisi ke-2. Cimahi: Trim Komunikata Publishing House;2015.

12. Boone WJ, Staver JR, Yale MS. Rasch analysis in human sciences. Edisi ke-1. Dordrecht: Springer; 2014.

13. Sumintono B, Widhiarso W. Aplikasi pemodelan Rasch pada assessment pendidikan. Edisi. Cimahi: Trim Komunikata Publishing House; 2015.

14. Rahmawati N. Hubungan kualitas pelayanan dengan kepuasan pelanggan pada pasien rawat inap RSUD Bangkalan. Jurnal Ilmiah Fakultas Psikologi Universitas Surabaya. 2014;3(1):1-10.

15. Khasanah I, Pertiwi OD. Analisis pengaruh kualitas pelayanan terhadap kepuasan konsumen RS St. Elisabeth Semarang. 2010 [diunduh 27 Agustus 2016]. Tersedia dari: www.jurnal.widyamanggala.ac.id/index.php/ asetwm/article/viewfile/35/28

16. Febriani VA, Sugiono. Analisis kualitas pelayanan terhadap kepuasan konsumen (Studi Pada Pasien Poliklinik Rawat Jalan Rumah Sakit Dr. Cipto Mangunkusumo). Diponegoro Journal of Management. 2012;1(1):1-10.

17. Herawati N, Qomariyah N. Pengaruh kualitas pelayanan puskesmas terhadap kepuasan pasien pengguna kartu pemeliharaan kesehatan masyarakat Surakarta (PKMS) di Surakarta. Bhirawa. 2015;2(2):1-10.

18. Venkatesh V, Orris G, Ackeran PLA. Longitudinal field investigation of gender differencesin individual technology adoption decision-making processes. Org Behav Hum Decis Proc. 2000;83(1):33-60.

19. Neti, Safitri W, Sunardi. Hubungan antara kinerja perawat dengan tingkat kepuasan pasien rawat inap di Puskesmas Kartasura. 2014 [diunduh 28 Juli 2016]. Tersedia dari: www.digilib.stikeskusuahusada.ac.id

20. Stefan M. Hubungan karakteristik pasien dengan kepuasan pasien terhadap mutu pelayanan kesehatan di Puskesmas Kecamatan Pesanggrahan Jakarta Selatan. Jakarta: STIKES Sint. Carolus; 2013. 